\title{
向精神薬服用患者の抗核抗体について
}

\author{
橋 本 博 史・赤 沢 滋*・津 田 裕 士 \\ 高崎 芳成・松本 孝夫・奈 須一 \\ 藤 巻 教子・鈴木 三佐子・塩川 優 一 \\ Paul I. Terasaki**, Yuichi Iwaki**
}

\section{Antinuclear Antibodies in Psychiatric Patients treated with Psychotropic Drugs}

\author{
Hiroshi Hashimoto, Shigeru Akazawa*, Hiroshi Tsuda, \\ Yoshinari Takasaki, Takao Matsumoto, Hajime Nasu, \\ Noriko Fujimaki, Misako Suzuki, Yuichi Shiokawa, \\ Paul I. Terasaki** and Yuichi Iwaki

\begin{abstract}
Juntendo University, School of Medicine, Department of Internal Medicine, Division of Rheumatology, * Psychology, ** UCLA, Surgery.
\end{abstract}

\section{【Summary】}

Antinuclear antibodies in sera obtained from 183 psychiatric patients treated with psychotropic drugs were studied.

Antinuclear antibodies (ANA) were detected by the indirect immunofluorescent method using rat liver cells as substrate. Farr assay was employed to determined the binding capacity for DNA. The immunoglobulin classes and complement fixing ability (CF) of anti-dsDNA were detected by the indirect immunofluorescent method and the complement fixation method, respectively, using Crithidia luciliae kinetoplasts as the substrate. Anti-ENA was detected by the hemagglutination test (PHA) and double immunodiffusion. Anti-histone was detected by the histone reconstitution of the immunofluorescent test. HLA typing for antigens of the $A, B$ and $C$ was performed by the standard lymphocyte microcytotoxicity test provided by the Terasaki laboratory. Typing for HLA-DR was performed on B lymphocytes isolated on nylon wool column. As controls, 75 normal Japanese individuals were tissue typed with the same antisera.

ANA was detected in 37 patients $(20.2 \%)$. Total doses of carbamazepine in the patients with ANA were significantly larger than in those without ANA. The patients with ANA had photosensitivity and oral ulceration significantly more than those without ANA. The patients 
with ANA had a tendency to have an association with HLA-DRw8.

Anti-DNA antibodies by Farr assay were detected in 25 patients, but titer of anti-DNA was low. Anti-dsDNA by Crithidia immunofluorescent technique was detected in two patients. However, CF of anti-dsDNA was not detected in any patients. Anti-ENA by PHA technique was detected in 21 patients. The patients with anti-ENA had arthralgia and hypergammaglobulinemia significantly more than those without anti-ENA. Anti-histone antibodies were detected in three patients, who were treated with chlorpromazine.

Key words : antinuclear antibodies, psychiatric patients, psychotropic drugs, SLE, HLA

\section{【概 要】}

向精神薬を服用している 183 例の精神病患者の血清を用いて, 各種抗核抗体を検索し投与薬剂, 薬剂投与量, SLE 様症状との関係について検討した。 また，抗核抗体陽性を認めた症例については，HLA 抗原の検索を行い，正常人と の比較検討を行った. その結果，䖝光抗体法による抗核抗体は 37 例に陽性を認め，これらは carbamazepine の投与 量が有意に多く，日光過敏症と口腔内潰瘍を認める症例む多かった．また, HLA -DRw 8 を有する症例も多い傾向に あった. Farr assay による DNA 抗体は 25 例に認められたが,いずれも抗体価は低值であった.

Crithidia による螢光抗体法では，2 例に dsDNA 抗体を認めたが補体結合性は認められなかった. PHA 法による ENA 抗体は 21 例に認め, 関節痛と高 $r$-gl. 血症を有する症例が多かった．抗ヒストン抗体は 3 例に陽性を認め, い ずれの症例む chlorpromazine 服用患者であった.

\section{I. 緒 言}

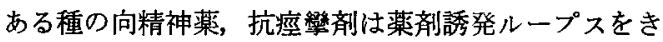
たすことが知られている，とくに，頻度の高い薬刜は hydantoin, trimethadione, ethosuximide である1). 他 方, chlorpromazineによる明らかな薬版誘発ループスの 報告は比較的少ないが2 4)，抗核抗体の出現率は $60 \%$ 以 上ともされている5).

一方, 薬剤誘発ループスは, 投与薬剤中止によりルー プス様症状の改善がみられることが特徴とされ，この点， 全身性エリテマトーデス（SLE）とは大きく異なる．両 疾患が病因論的に同一のものであるか否かは議論の多い ところであるが，抗核抗体の出現をみる点において共通 性が認められている。

今回，向精神薬服用患者血清中の各種抗核抗体を検索 し，それらの出現と投与薬郕，ループス様症状の有無， さらには HLA との関連性について検討し, SLE との異 同を考察したので報告する。

\section{II. 万 法}

1. 症例

183 例の向精神薬を服用している精神病患者を検討の 対象とした，その疾患，年齡，性，主たる治療薬郕を表 1 に示す.

\section{2. 抗核抗体の検索}

抗核抗体 (ANA) はラット肝細胞を基質とする䖝光抗 体法により検索し，その染色像と抗体価を観察した。 DNA 抗体は, ${ }^{125}$ I 標識 DNA を抗原とする Farr assay により検索した. ds-DNA 抗体とその免疫グロブリンク ラスおよび補体結合性は, Crithidia Iuciliae の kinetoplast を基質とする螢光抗体間接法 (CL-IF) と補体結合 法により検 索した ${ }^{6}$. Extractable nuclear antigen (ENA) 抗体は, PHA 法と二重免疫拡散法により検索し た7).ヒストン抗体は, reconstitution 法による煌光抗体 法で険索した ${ }^{8)}$ ，その方法を図 1 に示す. 
表 1 Clinical analysis of the patients treated with psychotropic drugs

\begin{tabular}{cc}
\hline total patients & 183 \\
male & 88 \\
female & 95 \\
age & $19 \sim 79$ yrs. \\
(mean 41.6yrs.) \\
diseases & 139 \\
schizophrenia & 12 \\
epilepsy & 7 \\
mental retardation & 6 \\
alcoholism & 5 \\
depression & 5 \\
neurosis & 12 \\
others & 14 \\
list of psychotropic & Drugs used \\
diphenylhydantoin & 66 \\
chlorpromazine & 91 \\
haloperidol & 89 \\
levomepromazine & 13 \\
carbemazepine & \\
\hline
\end{tabular}
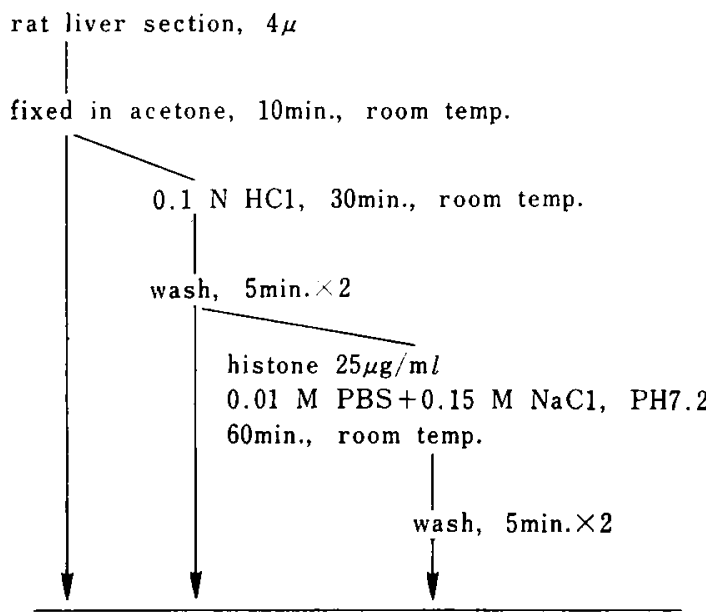

indirect IF for ANA

図 1 Method

\section{3、 HLA の検索}

HLA-A，B，C 抗原の検索は, Terasaki らの microlymphocytotoxity により, HLA-DR 抗原については, nylon wool column 法により Bリンパ球を分離し同様 の方法で行った．これらの HLA 検索は, 正常人 75 例 についても施行し，対照とした．表2に検索しえた HLA 抗原を示した.
表 2 HLA-A, B, C and DR antigens typed

\begin{tabular}{|c|c|c|c|}
\hline HLA-A & HLA-B & HLA-C & HLA-DR \\
\hline $\mathrm{AI}$ & B7 & CWI & DR1 \\
\hline A2 & $\mathrm{B} 12$ & $\mathrm{CW} 2$ & DR2 \\
\hline $\mathrm{A} 3$ & $\mathrm{~B} 13$ & CW3 & DR3 \\
\hline A9 & $\mathrm{B} 15$ & $\mathrm{CW} 4$ & DR4 \\
\hline $\mathrm{A} 10$ & BW 16 & CW6 & DR5 \\
\hline A11 & BW 22 & $\mathrm{CW} 7$ & DRW6 \\
\hline AW 19 & B27 & & DR7 \\
\hline $\mathrm{AW} 23(9)$ & BW 35 & & DRW 8 \\
\hline $\mathrm{AW} 24(9)$ & B37 & & DRW9 \\
\hline$A 26(10)$ & BW38(W16) & & \\
\hline A28 & BW39(W16) & & \\
\hline A29 & $\mathrm{B} 40$ & & \\
\hline AW 30 & $\mathrm{BW} 44(12)$ & & \\
\hline AW 31 & BW 46 & & \\
\hline AW 33 & BW 48 & & \\
\hline \multirow[t]{11}{*}{ AW 34} & BW $51(5)$ & & \\
\hline & BW $52(5)$ & & \\
\hline & BW54(W 22) & & \\
\hline & BW55(W 22$)$ & & \\
\hline & BW 56 (W 22 ) & & \\
\hline & BW $57(17)$ & & \\
\hline & $\mathrm{BW} 58(17)$ & & \\
\hline & $\mathrm{BW} 60(40)$ & & \\
\hline & $\mathrm{BW} 61(40)$ & & \\
\hline & BW62(15) & & \\
\hline & BW63(15) & & \\
\hline $\begin{array}{c}14 \\
\text { antigens }\end{array}$ & $\begin{array}{c}21 \\
\text { antigens }\end{array}$ & $\begin{array}{c}6 \\
\text { antigens }\end{array}$ & $\begin{array}{c}9 \\
\text { antigens }\end{array}$ \\
\hline
\end{tabular}

\section{4. 有意差検定}

$\chi^{2}$ 検定, $\mathrm{T}$ 検定を用いた。

\section{III. 結 果}

\section{1. 各種抗核抗体の陽性率}

螢光抗体法による抗核抗体は 37 例（20.2\%） に陽性 をみ, Farr assay による DNA 抗体は 25 例 (13.7\%)に 陽性をみた。 CL-IF 法による ds-DNA 抗体は 2 例 (1.1 \%)に陽性を認め，1例に IgA，M を他の 1 例に IgG， A，Mを認めたが，補体結合性は認められなかった。 Farr assay による DNA 抗体陽性例の抗体洒は 15.2 23.2 といずれる低值であった。

PHA 法による ENA 抗体は 21 例 (11.5\%) に陽性を 認めたが，二重免疫拡散法では，1 例にのみ抗 nRNP， 抗 Sm, 抗 SS-A, 抗 SS-B, 抗 PCNA 以外の未確認の沈 降線を認めた．ヒストン抗体は 3 例 $(1.6 \%)$ に陽性を認 めた. 
表 3 Staining patterns and titers of ANA in 37 patients treated with psychotropic drugs

\begin{tabular}{l|rrrrrrrrr|rr}
\hline patterns & $\times 5$ & $\times 10$ & $\times 20$ & $\times 40$ & $\times 80$ & $\times 160$ & $\times 320$ & $\times 640$ & $\times 1,280$ & $\times 2,560$ & \multicolumn{2}{c}{ total } \\
\hline peripheral & & & & & & & & & & 0 \\
homogenous & & & & 4 & 3 & 4 & 1 & 1 & 13 & $7.1 \%$ \\
speckled & 4 & 3 & 2 & 7 & 2 & & & & & 19 & $10.1 \%$ \\
nucleolar & 1 & & 1 & 3 & & & & & & & $2.7 \%$ \\
\hline
\end{tabular}

表 4 Titers of anti-ENA in 21 patients treated with psychotropic drugs

\begin{tabular}{l|ccccccc|cc}
\hline \multicolumn{1}{c|}{ titers } & $\times 80$ & $\times 160$ & $\times 320$ & $\times 640$ & $\times 1,280$ & $\times 2,560$ & $\times 4,000$ & \multicolumn{2}{|c}{ total } \\
\hline $\begin{array}{l}\text { anti-ENA } \\
\text { RNase resistant }\end{array}$ & 8 & 3 & 3 & 4 & 2 & 1 & 21 & $11.4 \%$ \\
ENA antibodies & 5 & 4 & 3 & 3 & 2 & 1 & 18 & $9.8 \%$
\end{tabular}

表 5 HLA-A and staining patterns of ANF induced by drugs

\begin{tabular}{c|cccc}
\hline HLA-A & $\begin{array}{c}\text { homogenous } \\
\mathrm{n}=10\end{array}$ & $\begin{array}{c}\text { speckled } \\
\mathrm{n}=6\end{array}$ & $\begin{array}{c}\text { nucleolar } \\
\mathrm{n}=2\end{array}$ & $\begin{array}{c}\text { controls } \\
\mathrm{n}=75\end{array}$ \\
\hline A-2 & 5 & $5^{*}$ & 2 & 30 \\
11 & 0 & 1 & 0 & 12 \\
W24 & 4 & 3 & 1 & 42 \\
26 & 1 & 1 & 0 & 17 \\
W31 & $5^{*}$ & 2 & 0 & 14 \\
\hline
\end{tabular}

* $\mathrm{p}<0.05$, corrected $\mathrm{P}$ value : N.S.

ANF : antinuclear factors

\section{2. 抗核抗体の染色像亡抗体価}

螢光抗体間接法による抗核抗体 (ANA) の染色像と抗 体価の関係についてみると，表 $3 の こ ゙ と く$ peripheral pattern は 1 例もなく, homogenous pattern は 13 例 (7.1\%)にみられ，その抗体洒は 40 倍より最高 2,560 倍まで認められた. Speckled pattern は 19 例 (10.1\%) に陽性を認め，その抗体価は 5 倍から 80 倍までであっ た. Nucleolar pattern は 5 例 $(2.7 \%)$ に陽性を認め, その抗体価は 5 倍から 40 倍までであった。

\section{ENA 抗体の抗体価}

PHA 法により 21 例に ENA 抗体を認めたが，二重免 疫拡散法では, nRNP 抗体, Sm 抗体, SSA 抗体, SSB 抗 体, PCNA 抗体以外の未確認の沈降線を 1 例に認めた. PHA 法による ENA 抗体価は，表 4 に示すごとくであ る. Total ENA 抗体の抗体価は 80 倍から 4,000 倍の幅 でみられ，また，RNase resistant ENA 抗体は，18例 (9.8\%) に陽性を恝め，その抗体価は，80倍から 4,000 倍の幅で認められた。

\section{4. 抗核抗体と HLA との関係}

螢光抗体閒接法による ANA の陽性例と正常人につい て HLA-DR の出現率を比較すると表 6 のごとくで， ANA 陽性例は正常人に比心゙ HLA-DRw 8 が有意に多く 認められた。しかし, corrected $\mathrm{P}$ を求めると有意差は 認められなかった．ANA の染色像では, homogenous 型 は Aw 31 と, speckled 型は A 2 と相関傾向がみられた (表 5).

また, PHA 法による ENA 抗体陽性例は, Bw 61 と相 関性が認められた。

\section{5. 各種抗核抗体と投与薬剂および投与量との関係} 結果は表 7 に示した.

ヒストン抗体陽性例は, 全例 chlorpromazine 投与例 で，ヒストン抗体陰性例に比べ chlorpromazine 投与例 が有意に多い $(\mathrm{p}<0.025)$. しかしながら，投与量との 関係では有意差は認められなかった，螢光抗体法による ANA の陽性例は，陰性例に比べ有意に carbamazepine の投与量が多い，それ以外の薬剂では，薬剤の種類，投 与量と抗核抗体出現の間に有意の関倸はみられなかっ 
表 6 HLA-DR and drug induced ANF

\begin{tabular}{r|ccccc}
\hline & $\begin{array}{c}\text { patients } \\
\text { with ANF } \\
\mathrm{n}=18\end{array}$ & $\begin{array}{c}\text { controls } \\
\mathrm{n}=75\end{array}$ & R.R. & $\mathrm{P}$ & Pc \\
\hline HLA-DR 1 & $3\left(16.7^{\circ} \circ\right)$ & $7\left(9.3^{\circ}\right)$ & 1.94 & N.S. & N.S. \\
2 & $6(33.3)$ & $21(28.0)$ & 1.29 & N.S. & N.S. \\
4 & $9(50.0)$ & $39(52.0)$ & 0.92 & N.S. & N.S. \\
W8 & $7(38.8)$ & $11(14.7)$ & 3.70 & p $<0.025$ & N.S. \\
\hline
\end{tabular}

ANF : antinuclear factors

R.R. : relative risk

$\mathrm{P}: \mathrm{P}$ value, $\mathrm{Pc}$ : corrected $\mathrm{P}$ value

表 7 Antinuclear antibodies and psychotropic drugs

\begin{tabular}{|c|c|c|c|c|c|c|c|c|c|c|c|c|c|c|c|}
\hline \multirow[b]{2}{*}{ Drugs } & \multicolumn{4}{|c|}{ ANA } & \multicolumn{4}{|c|}{ anti-DNA } & \multicolumn{4}{|c|}{ anti-ENA } & \multicolumn{3}{|c|}{ anti-Histone } \\
\hline & & $\begin{array}{c}+ \\
n=37\end{array}$ & & $\begin{array}{l}- \\
=146\end{array}$ & & $\begin{array}{c}+ \\
n=25\end{array}$ & & $=158$ & & $\begin{array}{l}+ \\
=21\end{array}$ & & $\begin{array}{l}- \\
=162\end{array}$ & & $\begin{array}{c}+ \\
n=3\end{array}$ & $\begin{array}{c}- \\
\mathrm{n}=180\end{array}$ \\
\hline diphenylhydantoin & 4 & $10.8 \%$ & 10 & $6.8^{\prime} \%$ & 1 & $4.0 \%$ & 13 & $8.2^{\circ} \circ$ & 2 & $9.5^{\circ} .0$ & 12 & $7.4^{\circ} \mathrm{O}$ & 0 & $\%$ & $7.8^{\circ} \circ$ \\
\hline chlorpromazine & 16 & 43.2 & 50 & 34.2 & 6 & 24.0 & 60 & 38.0 & 10 & 47.6 & 56 & 34.6 & 3 & $100.0^{* *}$ & $63 \quad 35.0$ \\
\hline haloperidol & 19 & 51.4 & 72 & 49.3 & 11 & 44.0 & 80 & 50.6 & 11 & 52.4 & 80 & 49.4 & 2 & 66.7 & $89 \quad 49.4$ \\
\hline levomepromazine & 17 & 45.9 & 72 & 49.3 & 10 & 40.0 & 79 & 50.0 & 10 & 47.6 & 79 & 48.8 & 2 & 66.7 & $87 \quad 48.3$ \\
\hline carbemazepine & 2 & 5.4 & 11 & 7.5 & 2 & 8.0 & 11 & 7.0 & 1 & 4.8 & 12 & 7.4 & 0 & & 7.2 \\
\hline
\end{tabular}

carbemazepine total dose:

$\left.\begin{array}{l}\text { ANA positive } 3,065,400 \pm 345,000 \mathrm{mg} \\ \text { ANA negative } \quad 234,207 \pm 436,473 \mathrm{mg}\end{array}\right\}: \mathrm{P}<0.05$

表 8 Antinuclear antibodies and lupus like manifestations in the patients treated with psychotropic drugs

\begin{tabular}{|c|c|c|c|c|c|c|c|c|c|}
\hline & \multicolumn{3}{|c|}{ ANA } & \multicolumn{2}{|c|}{ anti-DNA } & \multicolumn{2}{|c|}{ anti-ENA } & \multicolumn{2}{|c|}{ anti-Histone } \\
\hline & & $\begin{array}{c}+ \\
n=37\end{array}$ & $\begin{array}{c}- \\
n=146\end{array}$ & $\begin{array}{c}+ \\
n=25\end{array}$ & $\begin{array}{c}- \\
n=158\end{array}$ & $\begin{array}{c}+ \\
n=21\end{array}$ & $\begin{array}{c}- \\
n=162\end{array}$ & $\begin{array}{c}+ \\
n=3\end{array}$ & $\begin{array}{c}- \\
n=180\end{array}$ \\
\hline arthralgia & 2 & ${ }^{\circ}$ & $3{ }^{\circ}$ & 2 & 3 & $29.5^{\circ}$ & $\begin{array}{lr}3 & 0 \\
4 & 1.9\end{array}$ & 0 & 5 \\
\hline oral ulceration & 4 & $10.8^{* * *}$ & 10.7 & 2 & 3 & 1 & 2 & 0 & 5 \\
\hline photosensitivity & 2 & $5.4^{* * *}$ & $0 \quad 0$ & 1 & 1 & 0 & $\begin{array}{r}2 \\
25\end{array}$ & 0 & 2 \\
\hline leukopenia & 7 & & 24 & 4 & 27 & 6 & 3 & 1 & 30 \\
\hline hyper $\gamma$-globulinemia & 1 & & 4 & 1 & 4 & $29.5^{*}$ & 1.9 & 0 & 5 \\
\hline
\end{tabular}

た.

\section{6. 抗核抗体の出現とループス様症状}

表 8 に示すごとく，螢光抗体法による ANA の陽性例 は，陰性例に比べ，口腔内潰瘍と日光過敏症が有意に多 く，また, ENA 抗体の陽性例は陰性例に比べ, 関節痛と 高 $r$ ク゚ロブリン血症が有意に多いことを認めた。 DNA 抗体，ヒストン抗体の陽性例では，特徴ある臨床像は認 められなかった。
7. 各種抗核抗体と精神病，年齢，性との関係

精神病の疾患により抗核抗体の陽性率に相違があるか どうかをみると（表 9 )，とくに有意の相関は得られなか った.

また, 各種抗核抗体の出現と患者の年齡, 性について 検討したが，いずれも有意の相関は得られなかった。

\section{IV. 考察}

向精神薬を投与されている精神病患者の抗核抗体につ 
表 9 Antinuclear antibodies and psychiatric diseases

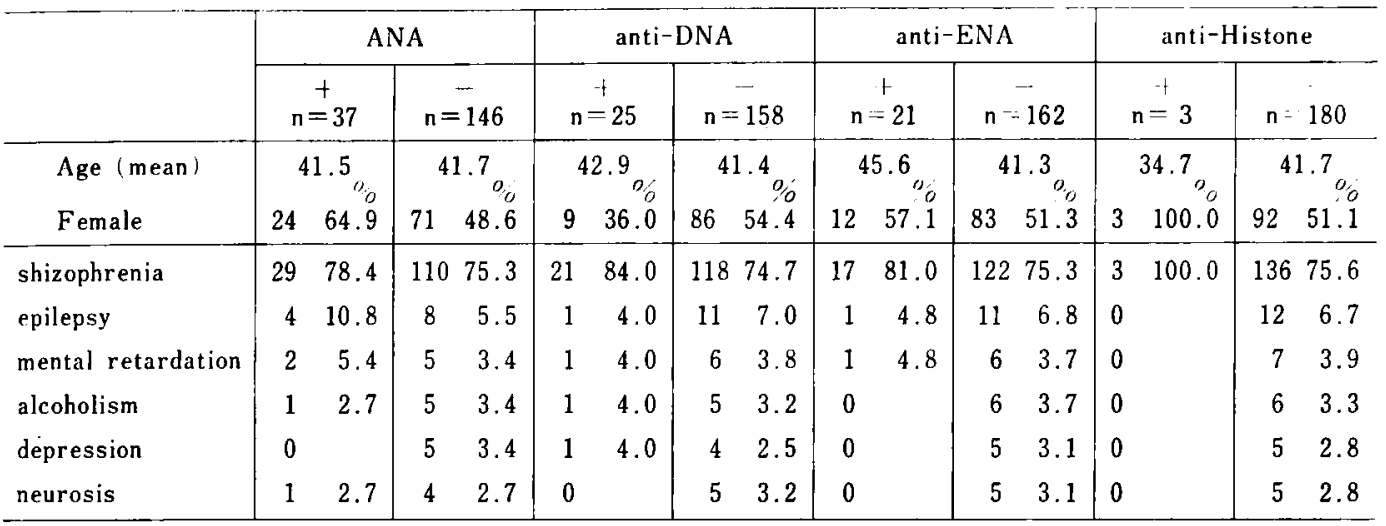

いての報告がこれまでいくつか報告されている 常人に比べて精神病の患者では，抗核抗体の出現率が高 く 17〜28\%の幅でみられ，それは精神病の疾患とは関 係せず, chlorpromazine $2,10,11)$ ないしは lithium carbonate ${ }^{12)}$ の治療と相関することが報告されている.

著者らは, 183 例の各種精神病患者の各種抗核抗体に ついて検討し，抗核抗体を $20.2 \%$ に認めたが，明らか に SLE 様症状を呈したものは，現在のところ1例む認 めていない，投与薬㓮および投与量と抗核抗体の出現と の関係について検討すると, carbamazepine 投与例では， 抗核抗体陽性を示す症例は，陰性例に比べ有意に投与量 が多く, carbamazepine 投与量と抗核抗体の出現に関連 性があることが示唆された. Carbamazepine 投与による 薬剤誘発ループスの報告はいまだないが，今後の経過が 重要視される. Chlorpromazine 投与例では, ヒストン 抗体を 3 例に認め，陰性例に比べ有意に多いことを認め た. ヒストン抗体は，薬剂誘発ループスで高頻度に出現 する可能性が示唆されて拈り，とくにプロカインアミド で高い(4). Chlorpromazine 投与とヒストン抗体との関 係については，いまだ詳細な報告はないが, Fabius ら9 により phenothiazine 系による抗核抗体の出現で, LE 因子が高頻度に証明されていることから, 今後さらに追 究されるべき課題と思われる。

SLE とは異なり綝剤誘発ループスでは, ds-DNA 抗体 の陽性率は低く，陽性を認めてもその抗体価は低い。こ のことが，ss-DNA 抗体やヒストン抗体の非補体結合性 の存在とともに，薬剤誘発ループスにおける非腎症に関 連していると考えられる15)。

今回, 著者らは, CL-IF 法により 2 例に ds-DNA 抗 体を認めたが，いずれむ補体結合性抗体は認められなか った. 薬丳誘発ループスにおける堅病変出現の低率は, ds-DNA 抗体価の低值のみならず，その抗体を噁めたと
しても補体結合性抗体が認められないことにも関連して いると考えられる.

各種抗核抗体の出現が SLE 様症状に結びっくかどう かは，重要な問題と思われる. 今回の検討では，螢光抗 体法による抗核抗体と口腔内潰瘍および日光過敏症の出 現が有意の相関を示し，また，ENA 抗体と関節痛および 高 $\gamma$ ーグロブリン血症が有意の相関を示した.しかしな がら，個々の症例を検討すると明らかに SLE が発症し た症例はない.日光過敏症は, chlorpromazine, thioridazine などの薬凧によってもたらされることが知られ て扣り ${ }^{16)}$ ，投与薬剤の影響も考えられる。

向精神薬投与による抗核抗体の出現機序にはいくつか のことが考えられる.SLE 発症の素因を有する症例で は,これらの薬剤により容易に SLE が発症することが 推測されるが, Alarcon-Segovia らは，抗痙攣威服用患

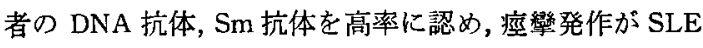
による可能性を示唆した ${ }^{17}$. 向精神薬投与による抗核抗 体の出現が HLA と関連するかどうか興味深いが，その 報告は少ない. Batchelor ら ${ }^{18)}$ は, hydralazine 誘発ル ープスと HLA との関係を検討し, HLA-DR 4 との相関 を認め，とくに DR 4 を有し，かつ slow acetylator の 女性に高頻度に認め, 真性 SLE とは異なる entity であ ることを報告した．合回の検討では，明らかな SLEの 発症は認めていないが，抗核抗体の陽性例は, HLA-DRw 8 と相関する傾向にあった. SLE ではほぼ 100\%抗核抗 体陽性であり，自験 SLE に扔ける HLA の検討では199， HLA-DR 2 との相関性が認められている.この西者の相 違をむってただちに結論するわけにはいかないが，向精 神薬投与による抗核抗体の出現が, SLE における抗核抗 体出現の免疫応答遺伝子と異なる可能性が考えられる. Procainamide, hydralazine, isoniazid では, acetyltransferase による代謝活性の速度, 核成分との結合によ 
る抗原性獲得の可能性について検討されているが，向精 神薬では未明である。また，山内ら ${ }^{200}$ は，hydralazineヒト血清アルブミンをウサギに免疫し，hydralazine 抗 体，DNA 抗体の産生を認め，薬剮と核成分との交文抗 原性のあることを示唆した．薬郕のアレルギー機序によ って薬片誘発ループスが発症することが知られている が，今回の向精神薬投与患者においては，多くは長期投 与患者で，臨床的に薬剤アレルギーを示したものはな く, Alarcon-Segovia ${ }^{21)}$ の作用機序による分類では，む しろ特殊な薬理学的性質によると思われる。 また，投与 薬剤の免疫能へ及ぼす影響も示唆される. 分裂病に用い られる薬剤は，プロラァチンの分泌を六進させ、これ は, プロスタブランディン, cAMP の增加をもたらし， 免疫抑制性を有することが報告されている23).そのほか， 加齡や性による影響も無視できないと思われるが，今回 検討した結果からは，各種抗核抗体の出現と性，年齡と の相関性は得られず，従来いわれている報告15) と一致す る所見と考えられた。

\section{V. 結 論}

向精神薬服用患者血清中の各種抗核抗体を検討し，以

1) Weinstein, A.: Drug-induced systemic lupus erythematosus. Progress in clinical Immunology. Edited by Schwartz, RS. Grune \& Stratton, 1980, pp 10.

2) Berglund, S., Gottfries, C.G., Gottfries, I. et al. : Chlorpromazine-induced antinuclear factors. Acta Med. Scand., $187: 67 \sim 74,1970$.

3) Dubois, E.L., Tallman, E. and Wonka, R.A. : Chlorpromazine-induced systemic lupus erythematosus. Case report and review of the literature. JAMA. $221:$ 595 596, 1972.

4) Ananth, J.V. and Minn, K.: Chlorpromazine induced systemic lupus erythematosus. Can Med. Assoc. J., $106:$ 680, 1973.

5) Zarrabi, M.H., Zucker, S., Miller, F., et al. : Immunologic and coagulation disorders in chlorpromazine treated patients. Ann. Intern. Med., 91 : 194 199, 1979.

6）橋本博史・歌川祐二 ·山形寿太郎 - 他：SLE K 㧍计る腎組織学的病変と血清中抗 native DNA 抗 体の免疫グロブリンクラス, 補体結合性ならびに
下の結論を得た。

1. 螢光抗体法に上る抗核抗体は， 37 例 $(20.2 \%)$ に 陽性を認め, 陽性例は carbamazepine の総投与量が有 意に多く, 臨床的に口腔内潰瘍と日光過敏症を有意に多 く認めた。

2. 抗核抗体陽性例は，HLA-DRw 8 と相関する傾向 がみられた。

3. Farr assay による DNA 抗体は 25 例 (13.7\%)に 認めたが，それらの抗体価は低い，CL-IF に上る梌索で は 2 例に陽性を認め, いずれも補体結合性抗体は認めら れなかった。

4. PHA 法による ENA 抗体は, 21 例 (11.5\%) に陽 性を認めたが，二重免疫抎散法では，1例に未確認の沈 降線が得られた. ENA 抗体陽性例は, 関節痛と高 $\gamma-ク ゙$ ロブリン血症を有意に多く認めた。

5. ヒストン抗体は 3 例 $(1.6 \%)$ に陽性を認め，全例 chlorpromazine 服用患者であった.

本論文は, 第 10，11 回日本臨床免疫学会で発表した. 本研究にあたり厚生省特定疾患自己免疫調查研究班の研 究費を使用した。

献

免疫複合体の組成について.リウマチ, $21: 366 \sim$ 374, 1981.

7) Nakamura, R.M., Greenwald., C.A., Peebles, C.M. and Tan, E.M. : Autoantibodies to nuclear antigens (ANA), American Society of Clinical Pathologists, USA, 1978, p. 82.

8) Tan, E.M., Robinson, J. and Robitaille, P.: Studies on antibodies to histones by immunofluorescence. Scand. J. Immunol., $5: 811 \sim 818$, 1976.

9) Fabius, A.J.M. and Ganlhofer, W.K. : Systemic lupus erythematosus induced by psychotropic drugs. Acta. Rheumatol. Scand., $17: 137 \sim 147$, 1971.

10) Quismorio, F.P., Bjarnason, D.F., Kiely, W.F., et al. : Antinuclear antibodies in chronic psychotic patients treated with chlorpromazine. Am J. Psychiatry, 132 : 1204 1206, 1975.

11) Gotlfries, C.G. and Gottfries, I. : Antinuclear factors in relation to age, sex, mental disease, and treatment with phenothiazines. Acta. Psy- 
chiater., Scand., (suppl) $255:$ 193 201, 1974.

12) Johnstone, E.C. and Whaley, K. : Antinuclear antibodies in psychiatric illness.: Their relationship to diagnosis and drug treatment. $\mathrm{Br}$. Med. J., 2 : 724 725, 1975.

13）川田一也：全身性エリテマトーデスに関する研究

（II）精神病患者における抗核抗体とその臨床的 検討. 臨床免疫, $9: 243 \sim 252,1977$.

14) Fritzler, M.J. and Tan, E.M. : Antibodies to histones in drug induced and idiopathic lupus erythematosus. J. Clin. Invest., $62: 560,1978$.

15）橋本博史：SLE VS 薬剤誘発ループス. メディチ 一ナ, $17: 2026 \sim 2027,1980$.

16) Satanove, A. and Mc Intosh, J.S. : Phototoxic reactions induced by high doses of chlorpromazine and thioridazine. JAMA., $200: 209,1967$.

17) Alarcön-Segovia, D., Fishbein, E., Reyes, P. A., et al. Antinuclear antibodies in patients on anticonvulsant therapy. Clin. Exp. Immu- nol., $12: 39 \sim 47,1972$.

18) Batchelor, J.R., Welsh, K.I., Tinoco, R.M., et al. : Hydralazine induced systemic lupus erythematosus : Influence of HLA-DR and sex on susceptibility. Lancet, $1: 1107 \sim 1109,1980$.

19）橋本博史・津田裕士 ・松本孝夫 ·他: SLEにおけ る HLA と臨床像, 免疫学的所見との関係につい て. 日内会誌, $72: 252,1983$.

20）山内康平：ヒドラジン誘発性ループス症候群の発 生機序に関する研究. リウマチ $19: 88 〜 104$, 1979.

21) Alarcon-Segovia, D. : Drug-induced lupus syndromes. Mayo Clin Proc., 44 : 664, 1969.

22) Horrobin, D.E.: Shizophrenia as a prostaglandin dificiency disease. Lancet, 1 : 936 937, 1977.

23) Sorrell, T.C., et al. : Depression of immunological function in patients treated with phenytoin sodium (sodium diphenylhydantoin). Lancet, 1233, 1971. 